Research.

\title{
Good corporate governance and tax avoidance to cost of debt with growth opportunity as moderating (empirical study on manufacturing company and finance service listed in IDX 2015-2019)
}

\author{
Sugiyanto ${ }^{1^{*}}$; Fitri Dwi Febrianti ${ }^{2}$;Suripto ${ }^{3}$ \\ ${ }^{1,2}$ Magister Management, Pamulang University; ${ }^{3}$ Departement of Accounting, Pamulang University \\ 1) dosen00495@unpam.ac.id; fitridwifebrianti@yahoo.co.id ${ }^{2)}$, 3) dosen00756@unpam.aci.id \\ * Corresponding author
}

Received: November 30, 2020; Accepted: December 18, 2020; Published: December 31, 2020.

To cite this article: Sugiyanto,S., Febrianti, F.D \& Suripto,S. (2020). Good Corporate Governance And Tax Avoidance To Cost Of Debt With Growth Opportunity As Moderating (Empirical Study On Manufacturing Company And Finance Service Listed In IDX 2015-2019). The Accounting Journal of BINANIAGA, 5 (2), 123140. doi: $10.33062 / a j b . v 5 i 2.406$

\begin{abstract}
Principles of good corporate governance can strengthen the relationship between the effect of Tax Avoidance, the Board of Commissioners and Managerial Ownership of the Cost of Debt on manufacturing companies listed on the Indonesia Stock Exchange (IDX). The hypothesis in the study uses the Eviews tool, tested 3 models 1) approach before using partial moderating (2) approach before using simultaneous moderating (3) The moderating growth opportunity. Samples consist of purposive sampling model with multiple linear regression analysis methods. The data used is the company's financial statements for 2015-2019. Research was taken from 28 selected manufacturing companies listed on the Indonesia Stock Exchange (IDX) and found samples 140 financial statements. The results of observation were obtained partially by Tax Avoidance has a significant effect on the Cost of Debt, the Board of Commissioners has not a significant effect on the Cost of Debt, and Managerial Ownership has a significant effect on Cost of Debt. While simultaneously Tax Avoidance, Board of Commissioners, and Managerial Ownership influence the Cost of Debt. The moderating of growth opportunity strengthens the relationship between Good Corporate Governance and positive coefficient on the cost of debt, strengthened by the Leverage and Size control variables.
\end{abstract}

Keywords: Independent Board of Commissioners, Managerial Ownership, Tax Avoidance, Growth Opportunity, Cost of Debt

\section{INTRODUCTION}

Ownership and management of the company is due to the existence of asymmetrical information between the two parties Jensen and Meckling (1976). The beneficiary is management (agent). Because you know more about the ins and outs of the company comparing with the shareholders (principal). The existence of asymmetrical information, it requires effective good corporate governance to reduce the occurrence of asymmetrical information by increasing supervision of management, to reduce liquidity risk borne by shareholders (Sugiyanto 2018). Managing a company that is effective and efficient is associated with optimal profitability. To get it, companies are required to

Sugiyanto; Fitri Dwi Febrianti; Suripto. Good Corporate Governance And Tax Avoidance To Cost Of Debt With Growth Opportunity As Moderating (Empirical Study on Manufacturing Company and Finance Service Listed in IDX 2015-2019) 
increase revenue and reduce the burden at a minimum level. One of the burdens of corporate governance is the tax burden.

Decisions are influenced by Good corporate governance for decision making by managers in determining the cost of equity and cost of debt so that company performance improves. In applying the principles of good corporate governance can reduce the negative or positive impact on the sustainability of the company in carrying out operations. First, by increasing supervision of management aimed at encouraging decision making: Second, preventing opportunistic actions in risk management that are not in accordance with company interests: Third, to reduce asymmetric information between management and shareholders.

Asymmetri information and the main contribution of the subject or object of an individual or entity tax, including payment of taxes, tax deductions, and tax collectors, who have tax rights and obligations in accordance with statutory regulations (Mardiasmo et al., 2011). In various efforts planned by company management to minimize tax burden aggressively, this is a phenomenon that is common throughout the country. Tax aggressiveness carried out by management to reduce the tax burden paid by the company (Lanis and Richardson, 2017). Tax aggressiveness that the government with taxpayers is very different from the view, that the company, by means of conducting tax aggressiveness aims to optimize and minimize the tax burden that does not violate regulations. This is with the government.

Brown (Santosa \& Kurniawan, 2016: 143) can be interpreted that tax avoidance is a regulation of transactions in order to obtain profits, and contributions, or tax deductions in a way that is unintended by tax regulations. Tax savings while tax expense by dividing pre-tax profit.

\section{LITERATURE REVIEW}

\section{A. Agency Theory}

Agency theory introduced by Jensen and Meckling (1976) in Sugiyanto and Etty (2018) arises when there is a contract between the manager (agent) and the owner (principal). A manager (agent) will know more about the condition of his company than the owner (principal). Management (agent) is obliged to provide information to the owner (principal). Managers as agents act in the interests of shareholders, Agency theory arises because it is assumed that managers act self interest (Sugiyanto and Etty 2018) define that agency relations as a contract where one or more principals use agents to carry out company activities.

In the agency theory meant by Principals is shareholders, owners or investors. While the agent is the management that manages the property of the owner in the company. The essence of the agency relationship is the separation of management from company ownership, so that the owner of the company can get the maximum benefit possible with the most efficient costs possible with the management of the company by professional staff.

The implementation of the contract raises costs which are referred to as agency costs, namely costs incurred so that managers act in harmony with the objectives of the owner, such as making contracts or conducting supervision. Tax avoidance behavior is influenced by the existence of agency theory because there are differences in interests between the parties, one side of the manager wants an increase in compensation, shareholders want to reduce tax costs, creditors want the company to fulfill the debt contract and pay interest. In this theory it is explained that the problem between the

Sugiyanto; Fitri Dwi Febrianti; Suripto. Good Corporate Governance And Tax Avoidance To Cost Of Debt With Growth Opportunity As Moderating (Empirical Study on Manufacturing Company and Finance Service Listed in IDX 2015-2019) 
principal and the agent arises because of the information asymmetry, this arises when a management has more information than a shareholder. The possibility of a manager reducing the information needed by a shareholder can harm the relevant shareholders. The researcher argues that the existence of agency theory is that the cost of debt can be influenced by agency problems, where one side of management wants to minimize taxes, on the other hand shareholders want to emphasize tax costs through low profits. So in order to mediate the agency problem, tax avoidance and the cost of debt are used to optimize their interests. Whereas for explain how contracting parties can design contracts whose purpose is to minimize costs as a result of information assimetry.

\section{Stakeholder Theory}

Internal and external parties that have a relationship with the company, and the stakeholders are influential and influenced by the company. From stakeholders, the continuity of the company to get company support must be able to contribute to its stakeholders (shareholders, creditors, consumers, suppliers, government, society, analysts and other parties). Stakeholder theory states that all stakeholders have the right to get information about company activities during certain periods that can affect decisionmaking.

Important aspects in stakeholder theory are rights and effects. The first aspect, namely rights, basically requires that the company and its managers must not violate rights and determine the future of stakeholders. The second aspect is the effect, requires that the management of the company is responsible for all actions taken. Independent board of commissioners and managerial ownership are influenced by stakeholder theory, namely to help company management in increasing value creation as a result of activities carried out and minimizing losses that may arise for their stakeholders. Sugiyanto, (2017). This theory states that all stakeholders have the right to obtain information about company activities that affect their company.

\section{Cost Of Debt}

External funding sources from creditors in the form of debt. For companies that owe, interest is a return that the company must give to creditors until the debt can be repaid. This rate of return will be the cost of debt for Marcelliana companies (in Santosa and Kurniawan, 2016: 142). Companies usually have debts not only to one creditor, but to several parties, where the interest rate determined by each party varies. Therefore, the cost of debt can be calculated using the weighted average of the interest expense that must be paid by the company by dividing the average short-term debt and the average long-term debt.

\section{Tax Avoidance}

Santosa and Kurniawan (2016: 143) Payment of income tax on the company is the transfer or transfer of wealth from the company to the government, the tax burden paid is a large cost for the company Therefore, companies will tend to do tax avoidance as a its efforts to be able to pay as efficiently as possible. Taxpayers always want small tax payments, which is why not a few taxpayers do tax evasion either legally or illegally. Legal avoidance is also called tax avoidance. Two important aspects in stakeholder theory are rights and effects. The first aspect, namely rights, basically requires that the company and its managers must not violate rights and determine the future of stakeholders. The second aspect is the effect, requires that the management of the company is responsible for all actions taken.

Sugiyanto; Fitri Dwi Febrianti; Suripto. Good Corporate Governance And Tax Avoidance To Cost Of Debt With Growth Opportunity As Moderating (Empirical Study on Manufacturing Company and Finance Service Listed in IDX 2015-2019) 


\section{Independent Board Of Commissioners}

Independent board of commissioners and managerial ownership are influenced by stakeholder theory, namely to help company management in increasing value creation as a result of activities carried out and minimizing losses that may arise for their stakeholders. Sugiyanto, (2017). This theory states that all stakeholders have the right to obtain information about company activities that affect their company.

\section{Board Of Commissioners}

Board of Commissioners is a party that has an important role in overseeing the performance of directors. It is considered to have better supervision of management because it is free from various internal interests of the company (Fama and Jensen in Sari, 2016: 27). According to Law No.40 of 2007 concerning limited liability companies, the board of commissioners is the organ of the company that is in charge of supervising in general and in accordance with the articles of association and giving advice to directors.An independent commissioner is a member of the board of commissioners who is not affiliated with management, other members of the board of commissioners and controlling shareholders, free from business relationships or other relationships that can affect his ability to act independently or act solely in the interests of the company. An independent commissioner is the best position to carry out a monitoring function to create a company that is good corporate governance. By measuring the number of independent commissioners dividing the total number of independent commissioners.

\section{Managerial Ownership}

Managerial ownership is a manifestation of the principle of transparency of good CG, managing a management company must be transparent so there is no conflict of interest with the shareholders as the owner. Management that owns shares will certainly harmonize it. Meanwhile the manager does not

\section{Firm Size}

The size of the company include total assets, log size, and stock market value (Sugiyanto, 2018). Because the greater the total assets, the greater the income. Riyanto (2010: 313) "The size of the company is seen from the amount of equity value, sales value or asset value. Sartono (2010: 249) is defined as follows: "Large companies that are well established will find it easier to obtain capital in the capital market compared to small companies. Because the ease of access means large companies have greater flexibility. " The larger the size of the company, the more the risk in terms of managing the tax burden. Companies that are included in large companies tend to have greater resources than companies that have a smaller scale to carry out tax management. Human resources who are experts in taxation are needed so that the tax management carried out by the company can be maximized to reduce the company's tax burden (Rego in Dewi and Jati, 2018).

\section{Leverage}

The operating costs of the company sourced from the company's debt are going accordingly. Funds are always to cover all or part of the costs needed, both short and long term funds. for operational costs. The magnitude of the use of funding sources must be considered so as not to burden the company, both short and long term. In other words, the use of funds from loans. The use of this funding source is known as debt or solvency or leverage ratio (Kasmir, 2015: 151). Managed shares are part of the company's ordinary share ownership by insiders (management) (Besley and Brigham, 2007: 146). Managerial ownership in this study can be measured using indicators of the number of

Sugiyanto; Fitri Dwi Febrianti; Suripto. Good Corporate Governance And Tax Avoidance To Cost Of Debt With Growth Opportunity As Moderating (Empirical Study on Manufacturing Company and Finance Service Listed in IDX 2015-2019) 
shares held by managerial parties divided by the total number of shares of the company. Thus to improve the performance of the company makes management will strive to make it happen so as to make the company's risk smaller in the eyes of creditors. The concept of thinking based on theorems related to Tax Avoidance Good Corporate Governance to Cost of Debt with moderation, with Growth opportunity and control variables Size and Leverage.

\section{Material And Methods}

The Framework for thinking theories Good Corporate Governance Tax Avoidance to Cost of Debt as moderation, Growth opportunity control variable. Size and leverage.

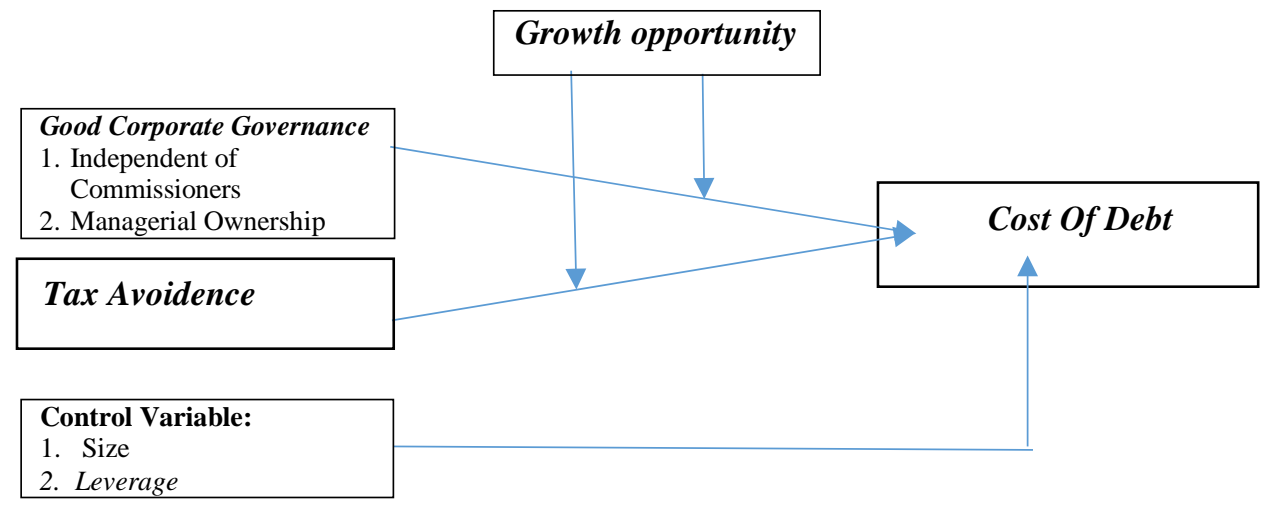

\section{Path Analisis Model}

\section{Hipothesis}

\section{Effect Tax Avoidance to Cost of Debt}

The company always strives for a high level of profit. Many expenses can reduce the expected level of profit, one of which is payment of taxes. Tax avoidance is deliberately carried out by the company in order to minimize the level of tax payments that must be made by the company. By doing tax avoidance, it is seen by creditors as risky actions, thus increasing the cost of debt (Masri and Martani, 2018). Tax avoidance is proven to cause the cost of debt to be greater, because creditors assess corporate tax avoidance behavior as a risk.

H1 :Tax Avoidance strengthens the Cost of Debt.

\section{Effect Independence Commissioner strengthens the Cost of Debt}

Board of Commissioners is a party that has an important role in overseeing the performance of directors. It is considered to have better supervision of management because it is free from various internal interests of the company (Fama and Jensen in Sari, 2016: 27). According to Law No.40 of 2007 concerning limited liability companies, the board of commissioners is the organ of the company that is in charge of supervising in general and in accordance with the articles of association and giving advice to directors. The proportion of independent commissioners has a significant positive effect on the cost of debt.

Based on the description above, the hypothesis can be concluded as follows:

H2 : Independence Commissionerstrengthens the Cost of Debt.

Sugiyanto; Fitri Dwi Febrianti; Suripto. Good Corporate Governance And Tax Avoidance To Cost Of Debt With Growth Opportunity As Moderating (Empirical Study on Manufacturing Company and Finance Service Listed in IDX 2015-2019) 


\section{The effect managerial commissioners to Cost of Debt}

Managerial Commissioners are share ownership by company management as measured by the percentage of shares held by management. Managerial ownership indicators used to measure managerial ownership represent the percentage of company or management share ownership by the director of the company compared to the number of outstanding company shares in the overall share of ordinary shares of the company by the insider (management) (Besley and Brigham, 2007: 146).Based on the description above, the hypothesis can be concluded as follows:compared with the number of outstanding company shares in the overall share of the company's ordinary shares by insiders (management) (Besley and Brigham, 2007: 146). Based on the description above, the hypothesis can be concluded as follows:

H3: Alleged Managerial Ownership influences the Cost of Debt

$\mathrm{H} 4$ :Growth opportunity strengthens the relationship between tax avoidance to the cost of debt.

H5: Growth opportunity strengthens the relationship between the Board of Commissioners and the cost of debt.

H6: Growth opportunity strengthens the relationship between Managerial Ownership of the cost of debt

\section{METHOD}

The method of this study is quantitative research, where the method used by the writer is quantitative descriptive method. This research was conducted at a manufacturing company listed on the Indonesia Stock Exchange (IDX) through its official website www.idx.co.id.

\section{Operational Variable Research}

The objectives of the study could be summarized as follow variables used in this study are divided into four variables, namely dependent variable, independent, moderating and control variables, and independent variables Tax Avoidance and GCG. The dependent variable is the Cost of debt. And the control variables are company size and leverage.

\section{Board of commissioners}

Board of commissioners by measuring references (Sugiyanto, et al 2016:49) Board of commissioners members who are not affiliated with management and shareholders who can influence the ability to act independently for the company are measured by the ratio as follows:

$$
D K=\frac{\text { Independence Commissioners }}{\text { Managerial Ownership }} \ldots \ldots \ldots \ldots \ldots . . . .1
$$

\section{Managerial ownership}

Measurement of CG reference proxies (Sari, et al 2018: 48) The principle of good transparency of good corporate governance, in managing management companies must be transparent so that there is no conflict of interest with shareholders as owners. By measuring the ratio level:

$$
K M=\frac{S M}{S B} \ldots \ldots \ldots \ldots \ldots \ldots \ldots \ldots \ldots \ldots \ldots \ldots \ldots
$$

Sugiyanto; Fitri Dwi Febrianti; Suripto. Good Corporate Governance And Tax Avoidance To Cost Of Debt With Growth Opportunity As Moderating (Empirical Study on Manufacturing Company and Finance Service Listed in IDX 2015-2019) 


\section{Tax Avoidance}

Measuring by reference (Hanum, 2013) Businesses to reduce or eliminate tax debt that must be paid by the company. By measuring the ratio level:

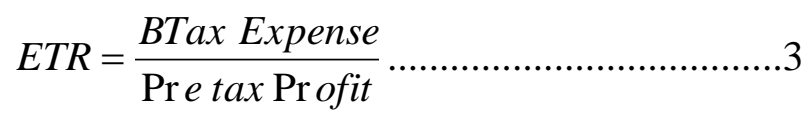

\section{Cost of debt}

Measurement of the cost of debt (Masri and Dwi in Suhartini, 2016: 41) the cost of debt is the rate of return desired by creditors when providing funding to companies. By measuring the ratio level as follows:

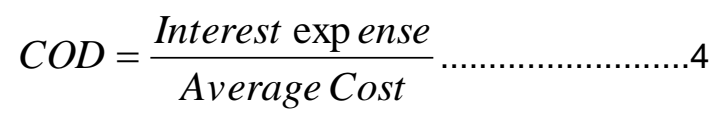

\section{Leverage}

Measuring the size of leverage and Size Sugiyanto (2018) The costs of its operations and the size of the company sourced from the company's debt are going accordingly. Funds are always to cover all or part of the costs needed, both short-term funds.

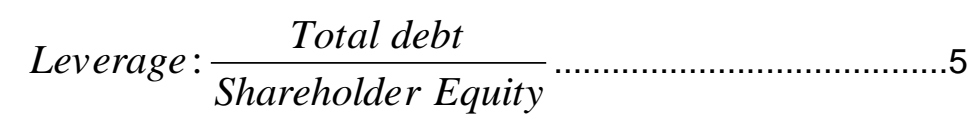

Firm Size : Ln Asset. .6

\section{Test MRA (Moderated Regression Analysis)}

The test calculation to prove whether growth opportunity as a moderating variable can strengthen or weaken the relationship between the tax Avoidence, Independence Commissioner and Managerial Ownership variables on the Cost of Debt by using the following equation:

$$
Y=\alpha+\beta 1 X 1+\beta 2 \times 2+\beta 3 \times 3+\beta 4 X 1 . Z+
$$

$\beta 5 X 2 . Z+\beta 6 X 3 . Z+\varepsilon \ldots \ldots \ldots \ldots \ldots \ldots . . .7$

Dimana:

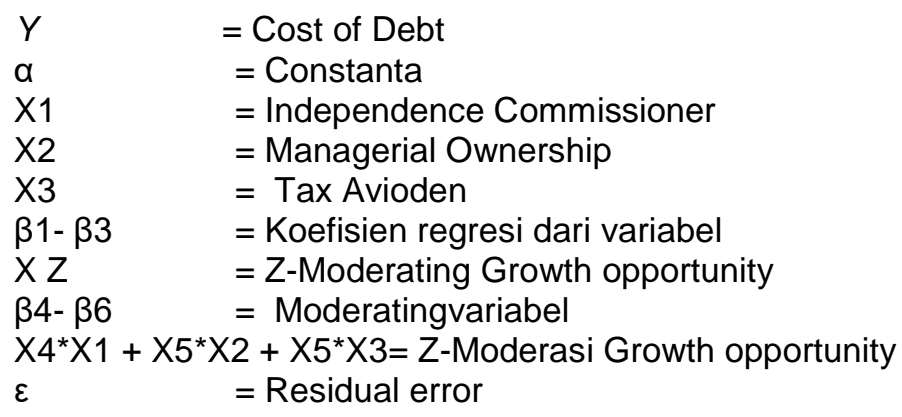

\section{Population and Sample}

The population referred to in this study are manufacturing companies listed on the Indonesia Stock Exchange in 2015-2019 and have been published. The reason this

Sugiyanto; Fitri Dwi Febrianti; Suripto. Good Corporate Governance And Tax Avoidance To Cost Of Debt With Growth Opportunity As Moderating (Empirical Study on Manufacturing Company and Finance Service Listed in IDX 2015-2019) 
research was conducted on the Indonesian stock exchange was that the data obtained had gone public and had been audited so that the results of this study could be significant. In accordance with the characteristics of the company which was used as a sample of the 5 years period of research from 2015 to 2019 .

\section{Analysis Techniques}

The analysis in this study will use Eviews 11. Before the previous data analysis is carried out the classical assumption test consists of normality test, multicollinearity test, autocorrelation test and heteroscedasticity test. Hypothesis testing uses a linear regression analysis test.The analysis in this study will use Eviews. Before the previous data analysis is carried out the classical assumption test consists of normality test, multicollinearity test, autocorrelation test and heteroscedasticity test. Hypothesis testing uses multiple linear regression analysis test. Then to find out whether the independent variable has an effect on the dependent variable either partially orsimultaneously, a t-test and F. statistical test are carried out. To find out how much influence the independent variables have on the dependent variable the coefficient of determination is used. The multiple linear analysis model used in this study is formulated as follows:

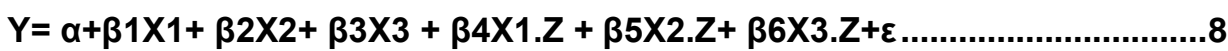

\section{RESULTS AND DISCUSSION}

\section{Descriptive Statistics}

Descriptive statistics describe the characteristics of each variable used in this study can be seen in table 1 below:

Table 1 Descriptive Statistics

\begin{tabular}{cccccccc}
\hline & $\begin{array}{c}\text { Independence } \\
\text { Commissioner }\end{array}$ & $\begin{array}{c}\text { Managerial } \\
\text { Ownership }\end{array}$ & $\begin{array}{c}\text { Tax } \\
\text { Avoidance }\end{array}$ & $\begin{array}{c}\text { Growth } \\
\text { opportunity }\end{array}$ & Leverage & Size & $\begin{array}{c}\text { Cost of } \\
\text { debt }\end{array}$ \\
\hline Mean & 0.377069 & 0.691673 & 0.298364 & 0.591673 & 0.491673 & 0.591673 & 0.034587 \\
\hline Maximum & 0.750000 & 0.984291 & 0.947617 & 0.984291 & 08947617 & 0.484291 & 0.269221 \\
\hline Minimum & 0.200000 & 0.013226 & 0.000251 & 0.013226 & 0.100251 & 0.213226 & 0.000541 \\
\hline Std. Dev. & 0.093326 & 0.194084 & 0.189526 & 0.094026 & 0.294012 & 0.394080 & 0.044727 \\
\hline Observations & 140 & 140 & 140 & 140 & 140 & 140 & 140 \\
\hline ource: The data processed using 2019 & & & & & & &
\end{tabular}

\section{Classic Asumption Test}

\section{Normality Test}

The normality test aims to determine the distribution of data in the variables used in the study. Data that is good and feasible to use in research is data that has a normal distribution. To test the assumption that the normality of the data is done using Jarque Berra (JB), if the JB probability is greater than 0.05 then the data is normally distributed, but if it is smaller than 0.05 then the data is not normally distributed (Ghozali, 2017)

Sugiyanto; Fitri Dwi Febrianti; Suripto. Good Corporate Governance And Tax Avoidance To Cost Of Debt With Growth Opportunity As Moderating (Empirical Study on Manufacturing Company and 


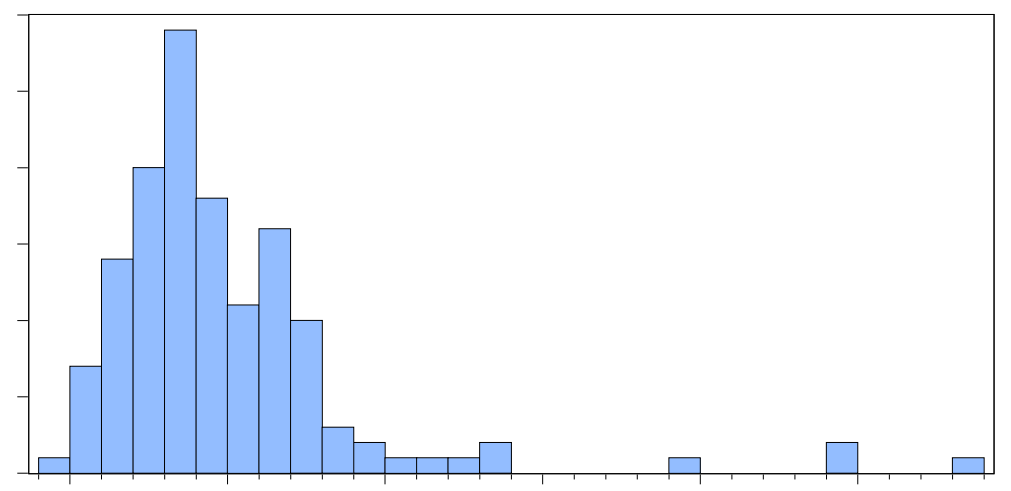

\begin{tabular}{|lr|}
\hline \multicolumn{2}{|l|}{ Series: Residuals } \\
Sample 2015 2019 \\
Observations & 140 \\
Mean & $-1.23 e-17$ \\
Median & -0.011062 \\
Maximum & 0.233824 \\
Minimum & -0.051758 \\
Std. Dev. & 0.042390 \\
Skewness & 2.976222 \\
Kurtosis & 14.55222 \\
Jarque-Bera & 985.1649 \\
Probability & 0.000000 \\
\hline
\end{tabular}

Figure 1 Normality after Transformation test

Based on the results above, it can be seen that the probability Jarque Berra value is 0.000000 , thus it can be concluded that the data from the variables in this study are not normally distributed. To treat normality can use the Log transformation method. The step is to transform the log by means of the Cost of Debt logarithmic logy $=\log (y)$ or logy $c x 1$ $\times 2 \times 3$. The results of the normality test using the Log will be presented as follow:

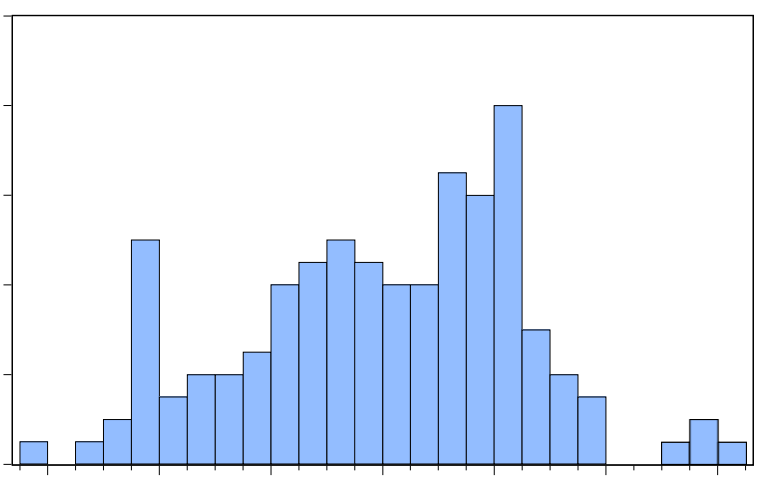

Figure 2 Normality before Transformation test
Series: Residuals

Sample 20152019

Observations 140

Mean $\quad-6.42 \mathrm{e}-16$

Median $\quad 0.109862$

Maximum $\quad 3.163082$

Minimum $\quad-3.034729$

Std. Dev. $\quad 1.254884$

Skewness $\quad-0.194562$

Kurtosis $\quad 2.532494$

Jarque-Bera $\quad 2.158211$

Probability 0.339899

Based on the results above it can be seen that the probability value of Jarque Berra is equal to $0.339899>0.05$ thus it can be concluded that the data from the variables in this study have been normally distributed

\section{Multicollinearity Test}

Multicollinearity test is used to test whether there is a relationship between independent variables. To detect the relationship between variables in this study by looking at Centered VIF between each variable. If it is greater than 0.10 , multicollinearity occurs in the regression model, but if the correlation coefficient between each variable is smaller than 0.10 , multicollinearity does not occur (Ghozali, 2017) will be presented in table 2

Sugiyanto; Fitri Dwi Febrianti; Suripto. Good Corporate Governance And Tax Avoidance To Cost Of Debt With Growth Opportunity As Moderating (Empirical Study on Manufacturing Company and Finance Service Listed in IDX 2015-2019) 
The Accounting Journal of BINANIAGA Vol. 05, No. 01, December 2020

p-ISSN: 2527-4309, e-ISSN: 2580-1481

$5^{\text {th }}$ Accreditation Rating: January 14, 2019 - January 13, 2024

Table 2 Multicollinearity test

\begin{tabular}{|c|c|c|c|}
\hline & Coefficient & Uncentered & Centered \\
\hline Variable & Variance & VIF & VIF \\
\hline Cost of Debt & 0.000465 & 35.44384 & NA \\
\hline Independence Commissioner & 0.000385 & 3.660010 & 1.046872 \\
\hline Managerial Ownership & 0.001520 & 17.47310 & 1.001797 \\
\hline Tax Avoidance & 0.000367 & 14.41430 & 1.045131 \\
\hline Growth opportunity & 0.000251 & 1.200000 & 1.013226 \\
\hline Leverage & 0.189526 & 1.093326 & 1.194084 \\
\hline Size & 0.100382 & 1.760010 & 1.146874 \\
\hline
\end{tabular}

Source: The data processed using 2019 Eviews 10

Based on table above, it can be seen in the Centered VIF column table. VIF values for variables that affect the Cost of debt with a value below 10. Because the VIF value of the three variables does not exist that is greater than 10 . Thus, the above model has been freed from the presence of multicollinearity.

\section{Heteroscedasticity test}

Heteroscedasticity test aims to test whether in the regression model variance occurs from a residual inequality to one other observation, then it is called Homoscedasticity and if it is different it is called Heteroscedasticity. A good regression model is Homoscedasticity or Heteroscedasticity does not occur. If in a regression model there is a problem of heteroscedasticity, it will cause the variance value to be no longer minimum. This will result in a standard error that cannot be trusted so that the regression results from the model cannot be justified (Ghozali, 2017). The method of knowing the presence or absence of heteroscedasticity symptoms in this study is by testing Glejser. If the significance of the prob * $R<0.05$, the model contains heteroscedasticity, and if the significance of the prob ${ }^{*} R>0.05$ then the model does not contain heteroscedasticity.

Table 3 Heteroskedasticity Test

\begin{tabular}{lll}
\hline & \multicolumn{1}{c}{ Heteroskedasticity Test: Glejser } \\
\hline F-statistic & 1.393220Prob. F $(3,136)$ & 0.2476 \\
\hline Obs*R-squared & 4.174304Prob. Chi-Square(3) & 0.2432 \\
\hline Scaled explained SS & 6.656989Prob. Chi-Square(3) & 0.0837 \\
\hline
\end{tabular}

Source: The data processed using 2019

Based on table 3 it can be seen that heteroscedasticity testing can be seen that the probibabilityobs * R-Squared $=0.2432$ or greater than 0.05 . So that it can be concluded that the data in this study variable did not have heteroscedasticity in this research model.

\section{Autocorrelation test}

The autocorrelation test aims to test whether in the linear regression model there is a correlation between confounding errors in period t with usage errors in the t- 1 period (before). Durbin Waston test is a way to test whether there is autocorrelation in this study. This value is usually called DW count. This value will be compared with the acceptance or rejection criteria to be made with the value of $\mathrm{dL}$ and $\mathrm{dU}$ determined based on the number of independent variables in the regression model $(\mathrm{k})$ and the number of samples (n). The values of $\mathrm{dL}$ and $\mathrm{dU}$ can be seen in Table DW with a significance level (error) of $5 \%(\alpha=0.05)$. Number of independent variables: $k=3$ Number of samples: $n=140$, namely:

Sugiyanto; Fitri Dwi Febrianti; Suripto. Good Corporate Governance And Tax Avoidance To Cost Of Debt With Growth Opportunity As Moderating (Empirical Study on Manufacturing Company and Finance Service Listed in IDX 2015-2019) 
The Accounting Journal of BINANIAGA Vol. 05, No. 02, December 2020 p-ISSN: 2527-4309, e-ISSN: 2580-1481

$5^{\text {th }}$ Accreditation Rating: January 14, 2019 - January 13, 2024

Table 4 Autocorrelation test

\begin{tabular}{llll}
\hline R-squared & 0.379958 & Mean dependent var & $-6.42 E-16$ \\
\hline Adjusted R-squared & 0.356822 & S.D. dependent var & 1.254884 \\
\hline S.E. of regression & 1.006397 & Akaike info criterion & 2.892542 \\
\hline Sum squared resid & 135.7199 & Schwarz criterion & 3.018612 \\
\hline Log likelihood & -196.4779 & Hannan-Quinn criter. & 2.943773 \\
\hline F-statistic & 16.42285 & Durbin-Watson stat & 1.957311 \\
\hline Prob(F-statistic) & 0.000000 & & \\
\hline
\end{tabular}

Source: The data processed using 2019

Based on table above, testing for autocorrelation using DW. It can be seen that $\mathrm{DW}=1.957311$, $\mathrm{DU}=1.7678,4-\mathrm{DU}=2.2322$. So that $1.7678<1.957311<2.2322$, it can be concluded that the data in this research variable does not have autocorrelation.

\section{Multiple Linear Regression Analysis test}

Dependent Variable: COD

Table 5 Multiple linear regression test

Method: Least Squares Included observations: 140

\begin{tabular}{lrrrr}
\hline \multicolumn{1}{c}{ Variable } & Coefficient & Std. Error & t-Statistic & \multicolumn{1}{c}{ Prob. } \\
\hline Independence Commissioner & 0.051119 & 0.021563 & 2.370697 & 0.0192 \\
\hline Managerial Ownership & 0.052479 & 0.019623 & 2.674319 & 0.0084 \\
\hline Tax avoidance & 0.006115 & 0.038983 & 0.156857 & 0.8756 \\
\hline Growth opportunity & -0.043205 & 0.019146 & -2.256566 & 0.0256 \\
\hline Leverage & 0.051119 & 0.031564 & 3.470693 & 0.0192 \\
\hline Size & 0.062479 & 0.029622 & 1.574314 & 0.0185 \\
\hline R-squared & 0.076115 & 0.018981 & 1.256855 & 0.0723 \\
\hline Adjusted R-squared & 0.101792 & Mean dependent var & 0.034587 \\
\hline S.E. of regression & 0.081979 & S.D. dependent var & 0.044727 \\
\hline Sum squared resid & 0.042855 & Akaike info criterion & -3.433844 \\
\hline Log likelihood & 0.249768 & Schwarz criterion & -3.349797 \\
\hline F-statistic & 244.3691 & Hannan-Quinn criter. & -3.399690 \\
\hline Prob(F-statistic) & 5.137541 & Durbin-Watson stat & 0.918589 \\
\hline Source: The data processed using 2019 & 0.002138 & & \\
\hline
\end{tabular}

Based on the results of testing the multiple linear regression analysis above it can be formulated an equation that explains the effect of tax avoidane, independent board of commissioners and managerial ownership of the cost of debt, namely:

COD : $0.051119+0.052479-0.006115-0.043205+0.0511190+0.062479+0.076115+e$

Sugiyanto; Fitri Dwi Febrianti; Suripto. Good Corporate Governance And Tax Avoidance To Cost Of Debt With Growth Opportunity As Moderating (Empirical Study on Manufacturing Company and Finance Service Listed in IDX 2015-2019) 


\section{Coefficient Determination test $\left(\mathbf{R}^{2}\right)$}

\section{Coefficient Determination test}

\section{Table 6 Coefficient Determination test}

\begin{tabular}{ll}
\hline $\begin{array}{l}\text { Dependent Variable: COD } \\
\text { Method: Least Squares Included } \\
\text { observations: } 140\end{array}$ \\
\hline Variable & Coefficient \\
\hline C & 0.051119 \\
\hline Tax avoidance & 0.052479 \\
\hline Independence Commissioner & -0.006115 \\
\hline Managerial Ownership & -0.043205 \\
\hline
\end{tabular}

\begin{tabular}{ll}
\hline R-squared & 0.101792 \\
\hline Adjusted R-squared & 0.081979 \\
\hline S.E. of regression & 0.042855 \\
\hline Sum squared resid & 0.249768 \\
\hline Log likelihood & 244.3691 \\
\hline F-statistic & 5.137541 \\
\hline Prob(F-statistic) & 0.002138 \\
\hline
\end{tabular}

Based on the results of the analysis presented in table 4.6, it is known that the coefficient of determination for the regression model between Tax Avoidance, Board of Commissioners and Management Ownership of Cost of Debt 0.101792. This value means that $10 \%$ of Cost of Debt can be explained by Tax Avoidance, Board of Commissioners and Managerial Ownership. Whereas 90\% of the Cost of Debt is explained by other variables which are not included in this research model.

\section{$t$ (partial) test}

Table 7 Partial Test and Simultan Test

Dependent Variable: COD Method: Least Squares

Included observations: 140

\begin{tabular}{lrrrr}
\hline \multicolumn{1}{c}{ Variable } & \multicolumn{1}{c}{ Coefficient } & \multicolumn{1}{l}{ Std. Error } & t-Statistic & \multicolumn{1}{l}{ Prob. } \\
\hline \multicolumn{1}{c}{ C } & 0.051119 & 0.021563 & 2.370697 & 0.0192 \\
\hline Ta avoidance & 0.052479 & 0.019623 & 2.674319 & 0.0084 \\
\hline Independence Commissioner & -0.006115 & 0.038983 & -0.156857 & 0.8756 \\
\hline Managerial Ownership & -0.043205 & 0.019146 & -2.256566 & 0.0256 \\
\hline R-squared & 0.101792 & Mean dependent var & & 0.034587 \\
\hline Adjusted R-squared & 0.081979 & S.D. dependent var & 0.044727 \\
\hline S.E. of regression & 0.042855 & Akaike info criterion & -3.433844 \\
\hline Sum squared resid & 0.249768 & Schwarz criterion & -3.349797 \\
\hline Log likelihood & 244.3691 & Hannan-Quinn criter. & -3.399690 \\
\hline F-statistic & 5.137541 & Durbin-Watson stat & & 0.918589 \\
\hline Prob(F-statistic) & 0.002138 & &
\end{tabular}

Source: The data processed using 2019

1. Tax Avoidance

The Tax Avoidance variable shows a coefficient of $5 \%$ (t-stat $=2.674319>1.97756)$ and prob. $0.0084<0.05$. Then it means that tax avoidance variables have a positive and significant effect on Cost of Debt.

2. Board of Commissioners

The Board of Commissioners variable shows a coefficient of $5 \%$ (t-stat $=-0.156857$ $<1,97756$ ) and prob. $0.8756>0.05$. Then it means that the board of commissioners variable has no significant effect on Cost of Debt.

Sugiyanto; Fitri Dwi Febrianti; Suripto. Good Corporate Governance And Tax Avoidance To Cost Of Debt With Growth Opportunity As Moderating (Empirical Study on Manufacturing Company and Finance Service Listed in IDX 2015-2019) 
3. Managerial Ownership

Managerial Ownership Variables at a coefficient of $5 \%(t-s t a t=-2.256566>1.97756)$ and prob coefficients. $0.0256<0.05$. Then it means that the Managerial ownership variable has a negative and significant effect on the Cost of Debt.

\section{F(Simultan) Test}

The $\mathrm{F}$ test is conducted to determine the effect of independent variables on the dependent variable simultaneously / together. The explanation of the results of the $F$ test has been presented in table 7 that the results of the $F$ test in this study have a coefficient of $5.137541>2.67$ with prob (F-statistic) of $0.002138<0.05$. This result means that the independent variables (Tax Avoidance, Board of Commissioners, Managerial Ownership) simultaneously / together have a significant influence on Cost of Debt.

\section{Discussion of Research Results}

Table 8

Regresi Moderating (Moderated Regression Analysis)

Dependent Variable: COD Method: Least Squares

Included observations: 140

\begin{tabular}{lrrrr}
\hline \multicolumn{1}{c}{ Variable } & Coefficient & Std. Error & t-Statistic & \multicolumn{1}{c}{ Prob. } \\
\hline Tax Aviodence & 0.051119 & 0.021563 & 2.370697 & 0.0192 \\
\hline Independence Commissioner & -0.052479 & 0.019623 & 2.674319 & 0.0084 \\
\hline Managerial Ownership & -0.043205 & 0.019146 & -2.256566 & 0.0256 \\
\hline Growth opportunity*Tax A & 0.051119 & 0.021563 & 2.370697 & 0.0192 \\
\hline Growth opportunity*DK & 0.052479 & 0.019623 & 2.674319 & 0.0024 \\
\hline Growth opportunity*KM & -0.006115 & 0.038983 & -0.156857 & 0.0046 \\
\hline Leverage & 0.051119 & 0.021563 & 2.370697 & 0.0022 \\
\hline Size & 0.052479 & 0.019623 & 2.674319 & 0.0004 \\
\hline R-squared & 0.101792 & Mean dependent var & 0.034587 \\
\hline Adjusted R-squared & 0.081979 & S.D. dependent var & 0.044727 \\
\hline S.E. of regression & 0.042855 & Akaike info criterion & -3.433844 \\
\hline Sum squared resid & 0.249768 & Schwarz criterion & -3.349797 \\
\hline Log likelihood & 244.3691 & Hannan-Quinn criter. & -3.399690 \\
\hline F-statistic & 5.137541 & Durbin-Watson stat & 0.918589 \\
\hline Prob(F-statistic) & 0.002138 & & & \\
\hline
\end{tabular}

Based on the results of Table 8 testing multiple linear regression analysis can be formulated equations that explain the influence of tax avoidane, independent board of commissioners and managerial ownership of the cost of debt with moderation of Growth Opportunity and Leverage and Size control variables obtained coefficients probability, namely:

$\mathrm{COD}=0.051119+0.052479-0.006115-0.043205+0.051119+0.052479+-0.006115+0.051119+0.052479+\mathrm{e}$

1. Effects of Tax Avoidance on Cost of Debt

The results of testing hypothesis 1 indicate that Tax Avoidance has a significant positive effect on the Cost of Debt, so the hypothesis 1 in this study is answered. The results of this study support Suhartini's (2015) research, with the results of tax avoidance having a significant positive effect on the cost of debt. It can be concluded 
that the higher the tax avoidance that is performed by the company as indicated by the low ETR, the higher the cost of debt that must be borne by the company. Conversely, the lower the tax avoidance done by a company is shown by a high ETR, the lower the cost of debt that must be borne by the company.

2. Effect of the Independent Board of Commissioners on Cost of Debt

The results of testing hypothesis 2 indicate that the board of commissioners has no significant effect on the Cost of Debt, so the hypothesis 2 in this study is not answered. This is presumably because the number of independent commissioners cannot limit the management in determining the amount of the debt. But it is different from the research conducted by Nugroho (Sulistyowati: 2015) which states that independent commissioners influence the cost of debt. This shows that the presence of the board of commissioners in the company is an important matter. Because the board of commissioners can prevent information asymmetry from management and shareholders.

3. Effect of Managerial Ownership on Cost of Debt

The results of testing hypothesis 3 show that Managerial Ownership has a significant negative effect on Cost of Debt. So that the bigger the share of the company's managerial ownership, the lower the cost of debt. In contrast to the research conducted by Juniarti and Sentosa (2009) which shows that managerial ownership does not affect the cost of debt. The existence of management ownership in the ownership of the company should establish an impetus for management to improve its performance besides according to Soebiantoro (in Juniarti and Sentosa (2009), management does not have control to determine debt policy because many are controlled by majority owners.

4. Effects of Tax Avoidance, Independent Board of Commissioners and Managerial Ownership of Cost of Debt.

Based on the results of the $\mathrm{F}$ test with a calculated $\mathrm{F}$ value greater than Ftable which is $5.137541>2.67$ with a significance value of $0.002138<0.05$. Thus it can be concluded that the variables of tax avoidance, board of commissioners and managerial ownership have a significant effect together on the cost of debt variable. This shows that when there is an increase and a decrease in the value of tax avoidance, the board of commissioners and managerial ownership, it will affect the cost of debt. The results of this study support the research conducted by Sulistiyowati (2016) which says that tax avoidance, independent board of commissioners and managerial ownership simultaneously influence the dependent variable, namely the cost of debt tested at a significant level of 0.05 . If the value of Fcount is greater than Ftable, it can be concluded that it affects the cost of debt.

5. Growth Opportunity strengthens the tax investment relationship to the cos of debt. The hypothesis of this study is that growth opportunity strengthens the relationship of tax avoids influencing the cost of debt in food and beverage consumption manufacturing companies listed on the Indonesia Stock Exchange in 2015-2019. Based on table 4.9, the results of the t statistical test for sales growth variables have a significant level. The significance level is greater than 0.05 , which means that $\mathrm{Ho}$ is rejected so that it can be said that sales growth does not significantly influence tax aggressiveness. Sales growth describes an increase in sales from year to year. The high level of sales growth shows the better the company is running its operations. Companies that have high sales growth rates will need more investment in various elements of assets, both fixed assets and current assets. Management needs to consider the appropriate funding sources for the expenditure of these assets. Companies that have high sales growth will be able to fulfill obligations such as tax

Sugiyanto; Fitri Dwi Febrianti; Suripto. Good Corporate Governance And Tax Avoidance To Cost Of Debt With Growth Opportunity As Moderating (Empirical Study on Manufacturing Company and Finance Service Listed in IDX 2015-2019) 
payments. The results of this study are in line with those carried out by Chriswono (2016) who found that Sales Growth had no significant effect on tax avoidance.

6. Growth Opportunity strengthens the Board of Commissioners' relationship to the cos of debt The moderation results in this study are moderation in strengthening GCG against the cost of debt in food and beverage consumption sector manufacturing companies listed on the Indonesia Stock Exchange in 2015-2019. Based on table 4.9, the results of the t test statistic for the liquidity variable have a significance level of. The significance level is greater than 0.05 , which means that Ho is rejected so that it can be said that liquidity does not have a significant effect on tax aggressiveness. The higher the liquidity ratio owned by the company indicates the company is in a healthy condition. But if the liquidity is too low, it will reduce the level of creditor trust in the company, resulting in a decrease in capital loans by creditors. In this research sample, the company that is the observation is able to maintain the level of liquidity so that there is no effect of liquidity on tax aggressiveness. This research result is in line with or consistent with the research by Wiwied Safitri (2016) showing that liquidity does not have a significant effect on tax aggressiveness.

7. Growth Opportunity strengthens the relationship of Managerial Ownership to the cost of debt. The research hypothesis is that growth opportunity strengthens the relationship between managerial ownership and influences the tax aggressiveness of food and beverage consumption sector manufacturing companies listed on the Indonesia Stock Exchange in 2015-2019. Based on table 4.9, the results of the $t$ statistical test for the size variable have a significance level of 0.019 . The significance level is less than 0.05 , which means that Ho is accepted so that it can be said that it has a significant effect on tax aggressiveness. The greater Managerial Ownership, it can be said that the transactions made by the company are increasingly complex. Company management will consider risks more in terms of managing their tax burden. Companies that are included in large companies tend to have greater resources than companies that have a smaller scale to carry out tax management.

\section{CONCLUSIONS}

The purpose of this study is to test and obtain empirical evidence regarding the effect of Tax Avoidance, Independent Board of Commissioners and Managerial Ownership of Cost of Debt. By moderating growth opportunity Based on the data that has been collected and then tested, it can be concluded as follows:

1. Tax Avoidance has a significant positive effect on the cost of debt. Based on the results of the t test the significance value is smaller than the level of significance. This means that if the tax avoidance by the company shown by ETR is low, the higher the cost of debt that must be borne by the company. Conversely, the lower the tax avoidance done by a company is shown by a high ETR, the lower the cost of debt that must be borne by the company.

2. The Board of Commissioners has no significant effect on the Cost of debt. Based on the results of the t test shows that the board of commissioners did not significantly influence the Cost of Debt, so this study was not answered. This is presumably because the number of independent commissioners cannot limit the management in determining the amount of the debt.

3. Managerial Ownership has a significant negative effect on the cost of debt. Based on the results of the $t$ test the significance value is smaller than the level of significance. It is assumed that the bigger the share of the company's managerial ownership, the lower the cost of debt. Large share ownership indicates that companies prefer

Sugiyanto; Fitri Dwi Febrianti; Suripto. Good Corporate Governance And Tax Avoidance To Cost Of Debt With Growth Opportunity As Moderating (Empirical Study on Manufacturing Company and Finance Service Listed in IDX 2015-2019) 
funding from stock issuance to funding from debt so that the cost of debt will be low.

4. Simultaneously tax avoidance, board of commissioners and managerial ownership influence the cost of debt. Based on the results of simultaneous tests $(F)$, the significance value of the cost of debt is smaller than the level of significance.

5. The results of moderating growth opportunity strengthen the relationship between tax avoidance, board of commissioners and managerial ownership influence the cost of debt. Based on the results of simultaneous tests $(F)$, the significance value of the cost of debt is smaller than the level of significance.

\section{Limitations}

This research can not be separated from the limitations - limitations that require improvement and development in subsequent studies. Limitations of this study include: In the dependent variable (cost of debt) using the interest expense gauge by dividing the average loan, but using this formula the data does not pass sothat the researcher uses another measure, namely interest expense by dividing the average liability so that the data processed in eviews get away with the conditions specified.

1. In processing the data there is normality so that it does not pass the normality test and must use a normality transformation to pass the normality test requirements.

2. Suggestions

3. Based on the conclusions and limitations above, some suggestions that can be proposed are as follows:

1. For creditors, it is best to understand financial information presented by the company, one of which is good corporate governance, so that it is not wrong to invest and get a return as expected in investing.

2. For companies it is recommended to increase creditor trust in the company, by improving the quality of information presented, namely relevant and reliable.

3. For further researchers who are interested in researching the same title. It is expected to be able to research all companies listed on the IDX, extend the year of research, and increase the number of samples.

\section{REFERENCES}

Besley dan Brigham. (2007). Tax Shelters and Corporate Debt Policy. Journal of Financial Economics.

Ghozali,I. (2017). Analisis Multivariat dan Ekonometrika, Teori, Konsep, dan Aplikasi dengan Eviews 8.

Juniarti \& Sentosa, A.A. (2009). Pengaruh Good Corporate Governance, Voluntary Disclosure terhadap Biaya Utang . Junal Akuntansi \& Keuangan. 11(2), ,88-100.

Kasmir. (2015). Analisis Laporan Keuangan. Rajawali Pers

Mardiasmo. (2011). Perpajakan Edisi Revisi”. Yogyakarta: Andi.

Masri,I. \& Martani,D. (2012). Pengaruh Tax Avoidance terhadap Cost of Debt. Simposium Nasional Akuntansi XV, 1-28.

Rahmawati. (2015) Pengaruh Penghindaran Pajak dan Good Corporate Governance terhadap Biaya Utang. [Skripsi Universitas Negeri Padang]

Sugiyanto; Fitri Dwi Febrianti; Suripto. Good Corporate Governance And Tax Avoidance To Cost Of Debt With Growth Opportunity As Moderating (Empirical Study on Manufacturing Company and Finance Service Listed in IDX 2015-2019) 
Riyanto, B. (2010). Dasar-Dasar Pembelanjaan Perusahaan Edisi Keempat. BPFE. Yogyakarta.

Santosa,J.E. \& Kurniawan, H. (2016). Analisis Pengaruh Tax Avoidance terhadap Cost of Debt. Journal. MODUS , 28 (2),139-154..

Sari, G. (2016). Pengaruh Struktur Kepemilikan dan Karakteristik Dewan Komisaris terhadap Agresivitas Pajak dengan Ukuran Perusahaan sebagai Variabel Moderating. [Skripsi,Universitas Pamulang].

Sartono, A. (2010). Manajemen Keuangan Teori dan Aplikasi Edisi Keempat, BPFE. Yogyakarta.

Sugiarto, T,Madu,L., Subagyo,A.,Sugiyanto,Achmadi. (2018). International Application Model Short Long Term Berween GNP and Cunsumption: Case study Indonesia .Journal Economics , 6(1). doi: 10.2478/eoik-2018-0004

Sugiyanto (2018) Effect Ratio Keuangan Perusahaan Pada Model Prediksi Kepailitan Perbankan Model Altman Z-Score dengan Moderasi Good Corporate Governance. Parade Riset Akuntansi. III (PRA) 2018

Sugiyanto (2018) Good Corporate Governance Conservatisme Accounting, Real Earnings Management And Information Asymmetry On Share Return Prosiding Seminar Internasional Seminar lai Jabar Dan Coll For Papers Riset Akuntansi Universitas Pamulang, 21 April 2018.

Sugiyanto (2018) Good Corporate Governance Conservatisme Accounting, Real Earnings Management and Information Asymmetry on Share Return. Prosiding Seminar Internasional Seminar IAI Jabar dan Coll For Papers Riset Akuntansi di Universitas Pamulang, 21 April 2018

Sugiyanto, (2017) Conservatisme Accounting, Real Earnings Management and Information Asymmetry on Share Return. Iternational Journal of Core Engineering \& Management , 4

Sugiyanto, S. (2018). Pengaruh Tax Avoidance Terhadap Nilai Perusahaan Dengan Pemoderasi Kepemilikan Institusional. Jurnal IImiah Akuntansi Universitas Pamulang, 6(1), 82-96.

Sugiyanto, S., \& Candra, A. (2019). Good Corporate Governance, Conservatism Accounting, Real Earnings Management, And Information Asymmetry On Share Return. Jiafe (Jurnal IImiah Akuntansi Fakultas Ekonomi), 4(1), 9-18.

Sugiyanto, S., \& Candra, A. (2019). Good Corporate Governance, Conservatism Accounting, Real Earnings Management, And Information Asymmetry On Share Return. Jiafe (Jurnal IImiah Akuntansi Fakultas Ekonomi), 4(1), 9-18.

Sugiyanto, S., \& Candra, A. (2020). Moderating Good Corporate Governance Effect Sales Growth, Conservatisme Accounting And Liquidity Risk Terhadap Agresivitas Pajak (Studi Pada Perusahaan Manufaktur Dan Jasa Keuangan Terdaftar Bei). In Proseding Seminar Nasional Akuntansi, 2(1)

Sugiyanto; Fitri Dwi Febrianti; Suripto. Good Corporate Governance And Tax Avoidance To Cost Of Debt With Growth Opportunity As Moderating (Empirical Study on Manufacturing Company and Finance Service Listed in IDX 2015-2019) 
The Accounting Journal of BINANIAGA Vol. 05, No. 01, December 2020

p-ISSN: 2527-4309, e-ISSN: 2580-1481

$5^{\text {th }}$ Accreditation Rating: January 14, 2019 - January 13, 2024

Sugiyanto, S., \& Candra, A. (2020,). Moderating Good Corporate Governance Effect Sales Growth, Conservatisme Accounting And Liquidity Risk Terhadap Agresivitas Pajak (Studi Pada Perusahaan Manufaktur Dan Jasa Keuangan Terdaftar Bei). In Proseding Seminar Nasional Akuntansi (Vol. 2, No. 1).

Sugiyanto, S., \& Sumantri, I. I. (2019). Peran Audit Internal Dan Sistem Pengendalian Internal Atas Pengajuan Kredit Tanpa Agunan Pada Perusahaan Perbankkan Di Indonesia. Jurnal Akuntansi, 13(2), 196-224.

Sulistiyowati. (2016) Pengaruh Good Corporate Gavernance dan Tax Avoidance terhadap Biaya Utang. [Skripsi Universitas Pamulang].

http://www.ldx.co.id,

http://www.sahamOk.com

Laws No. 28 Tahun 2007.

Laws No. 40 Tahun 2007.

Sugiyanto; Fitri Dwi Febrianti; Suripto. Good Corporate Governance And Tax Avoidance To Cost Of Debt With Growth Opportunity As Moderating (Empirical Study on Manufacturing Company and Finance Service Listed in IDX 2015-2019) 